\title{
Sculpture, Diagram, and Language in the Artwork of Joseph Beuys
}

\author{
Wolfgang Wildgen
}

\begin{abstract}
The artwork of Joseph Beuys was provocative in his time. Although he was very successful on the international art scene and on the art market, the larger public is still bewildered by his Fat Chair or his installations and his performances. The article shows the evolution of his artwork from classical materials (stone, steel) to soft materials (animals, products of animals) and further to his concept of "social sculpture" and to programmatic diagrams (with words and graphics). A special point of interest is the transition towards language (phonic and conceptual), the philosophy of art exposed in his drawings, and diagrams and the relation between art and science in his artwork.
\end{abstract}

Keywords (Beuys) $\bullet$ Language $・$ Diagram $・$ Performance $・$ Politics $・$ Social sculpture

\section{Introduction}

Aesthetic norms and values have two faces: an individual and a social (collective) face. The collective face may be highly ordered and symmetric as art and public displays in totalitarian states demonstrate, but it can very suddenly break down into chaotic modes. The destroyed towns of Germany and Japan after 1945 are the counter-image to the ordered troop parades in totalitarian regimes. The individual face gains its value from the opposition to established norms, habits, and conventionalized shapes; it displays local beauty under specific perspectives. It lives from surprise, provocation, deviance, and lack of conventionalized contents. In the case of language, grammars and lexicons of a standard language show the collective face of signs; slam poetry or spontaneous wit, the individual one. In the case of visual art, academic art (mainly before 1850) is akin to standard language whereas

\footnotetext{
W. Wildgen $(\bowtie)$

Faculty of Languages and Literatures, Institute of General and Applied Linguistics, University of Bremen, Bremen, Germany

e-mail: wildgen@uni-bremen.de; homepage: http://www.fb10.uni-bremen.de/lehrpersonal/ wildgen.aspx
} 
avant-garde artists after 1912 elaborated the individual face. In the period after 1945, with the breakdown of fascist regimes (later of the Stalinist analogues), the individualistic mode in art, which had survived in non-totalitarian countries and in emigration, became dominant again. Major philosophical aspects of the opposition are treated by Simmel's (1896) book Soziologische Ästhetik, which sees aesthetic principles at work in the construction and preference for political and social types of organization. A common feature of socialistic utopias is: "that society as a whole should become an artwork" ("Daß die Gesellschaft als Ganzes ein Kunstwerk werde," Simmel 1896/2008, p. 147).

In the following, I shall concentrate on Joseph Beuys, whose career had only begun in the late fifties when Germany reappeared as a global player in the international political and cultural scene. Contrary to another prominent and provocative modern artist, Jackson Pollock (1912-1956; cf. Wildgen 2010b, 2013, ch. 4.4), Beuys was himself a theoretician of art engaged in cultural politics and a protagonist of the rapidly changing scene of avant-garde art in Europe and America in the sixties and seventies.

\section{Context and Development of Beuys' Artwork}

Joseph Beuys was born in 1921 in Germany. Immediately after high school in 1940, he became a soldier (a radioman in an aircraft, later a pilot until 1945). After a period in prisoner camps (1947), he studied at the Art Academy in Düsseldorf (mainly sculpture). Beuys' motivation for art was different from that of most of his teachers and co-students. He combined a strong interest in biology (and other natural sciences) and philosophy (with a specific preference for the lineage: Goethe Humboldt - Steiner) with interests in art (Beuys mentions the sculpture of Wilhelm Lehmbruck as his basic impulse). This basic reorientation explains why his art transports more complex messages that are not just meant for aesthetic pleasure.

In 1961, he was appointed professor of monumental sculpture at the Academy of Düsseldorf. After 1962, he joined the "Fluxus" movement for some time, which, following the tradition from Dadaism, aimed at an art based on performance and multi-mediality (music played a central role). In 1963, he organized the "International Festum Fluxus Fluxorum." The eminent conceptual level of Beuys' artwork was developed beyond the Fluxus-movement, when Beuys included politics in his artistic program and applied his political ideas to decisions in the Art Academy in Düsseldorf where he was teaching. Eventually, he decided to accept all students who had applied and to ignore the "numerus clausus" imposed by the Minister of Education. This led to a conflict with the minister, Johannes Rau (who became later Federal President of Germany). In 1969, Rau fired Beuys because he and his students had occupied the office of student inscriptions (Beuys argued that they had just gone there in order to get all of them enrolled). After several years of struggles in court, his sudden dismissal was cancelled (1978), but as he did not have tenure, his contract had ended anyway. He later got the right to use a room 
at the Academy and work there (without becoming a member of the staff). Beuys stopped teaching (although he had the opportunity to continue his educational work in Vienna) and concentrated his energies on expositions, actions, and his artwork, e.g., his repeated participation in the Documenta in Kassel, the foundation of an International University for Creativity and Interdisciplinary Research, and events of performance art in New York, Edinburgh, Basel, and many other places. Beuys died in Düsseldorf in 1986.

$\mathrm{He}$ is surely an intriguing figure in modern art and many visitors to museums remain bewildered when they experience his artworks. Nevertheless, his longlasting international success shows that his art triggered many significant reactions and contained a message to his public that was understood by many colleagues, collectors, and critics of art (he also had some famous pupils). If the general public is rather reluctant in appreciating such art, this seems to be a general characteristic of avant-garde art. But what is the message of Beuys' artwork? Is the kind of very complex, abstract, and performance-oriented artwork an expression of new aesthetic norms or are aesthetic norms part of the traditions that are negated?

In the following, I shall consider innovative art insofar as it explores the means and channels of possible signs (including their limits) in the human world. It may help us understand how human communication and signs work. I shall begin considering the visual materials used by Beuys in the development of his art.

\section{Materials and Techniques in Beuys' Artwork}

When Beuys studied at the Academy of Art in Düsseldorf, he had as his major teacher the sculptor Mataré (1885-1962). As Mataré's master student, he mainly produced sculptures in stone and iron (sepulchral and religious art). In 1952, he created a fountain in steel commissioned but not accepted by a steel company in Krefeld. It became in 1984 part of the installation "Barraque D'Dull Doddle." Very soon, he added organic material (plants and animals): deer, elks, sheep, hares, bees; and animal matter: wax, honey, grease (derived from animal fat), and felt (derived from the fur and hair of sheep). In the further course of his artistic development, the materials became more numerous (complex) and more dynamic. Performances became the center of his activities. Major examples are:

- In 1965, Beuys explained his drawing to a dead hare; his head was covered with honey and then with 50 dollars worth of gold leaf.

The gallery was closed to the public and Beuys' action was witnessed only by the photographer Ute Klophus and a television crew. Beuys sat on a chair in one corner of the gallery, next to the entrance. He had poured honey over his head, to which he had then affixed fifty dollars worth of gold leaf. In his arms he cradled a dead hare, which he looked at steadfastly. Then he stood up, walked around the room holding the dead hare in his arms, and held it up close to the pictures on the walls; he seemed to be talking to it. Sometimes he broke off his tour and, still holding the dead creature, stepped over a withered fir tree that lay in the middle of the gallery. All this was done with indescribable tenderness and great concentration. (Stachelhaus 1987, p. 13). 
For pictures of this action see: http://uploads3.wikipaintings.org/images/ joseph-beuys/how-to-explain-pictures-to-a-dead-hare.jpg

- In 1974, he lived 3 days on stage in a New York gallery together with a coyote.

- In 1982, he began to plant 7,000 oak tress in Kassel, each one accompanied by a basalt stone.

Some halting marks of his sculptural work (first in the traditional sense as threedimensional objects made by an artist) are: Kreuzigung (crucifixion) 1962/1963; Staatsgalerie Stuttgart (cf. for a picture in the net: http://www.staatsgalerie.de/ media/malereiundplastik/bis1980_beuys_1.jpg) and "Fettstuhl” (Fat Chair, 1963, Hessisches Landesmuseum Darmstadt; cf. for material in the net, e.g. http:// kitchentalkblog.files.wordpress.com/2013/02/beuys-fettstuhl.jpg).

In a classical iconographic analysis, the first sculpture reproduces the crucifixion scene with John and Mary contemplating Jesus on the cross (cf. the title of Beuys artwork). The bottles were containers of blood and stand for living bodies, the Red Cross stands for Jesus and his service for humanity. The materials are poor; without material value and thus fulfill criteria of minimal art. However, basic meanings and references to cultural values have been conserved. Nevertheless, one cannot imagine that this artwork could function in the context of Christian ceremonies. In this sense, it negates the contextual value given to religious art (cf. Wildgen 2010a, 2013, ch. 3.1.7 for the transformation of the topic "Last supper" in modern art).

The chair is a classical design object (cf. Beyaert 2012), but the chair chosen by Beuys is a very simple and poor token; the mass of fat "sitting" on the chair may stand for the human being reduced to the energy reserve of his body (fat). The human body is geometrically abstracted to the half of a cube (itself a platonic solid), with a smooth quadratic surface and a coarse triangular side. Solids of fat were a frequent form in Beuys' sculptures. Their contrary parts are basalt cylinders or columns such as those used in the installation "7,000 oaks."

In the sixties (first in 1967, as a professor in Düsseldorf) and in the seventies, Beuys began to enlarge and redefine his concept of sculpture and art and created the concept of "social sculpture" ('soziale Plastik'). The materials are not only of organic and animal origin, but they are also social and political (society, humanity). Thus, Beuys expanded the type of materials for "sculpture":

- From stone and steel to "warm" materials (wax, honey, grease, animals).

- From sign-using individuals (animals, humans) to social and political entities and even to humanity as a whole.

As a consequence, he sketched the program of a new political movement that, together with other currents, contributed to the foundation of the "Green Party" in Germany and Beuys even stood on the list for the first elections in which they participated. After his dismissal as professor at the Academy of Art, he also initiated a program for alternative universities. Thus the "Free International University of Creativity and Interdisciplinary Research," first conceived in a German context (1974; together with e.g. Heinrich Böll), was realized in Ireland (Dublin, Belfast, and Derry). 
Beuys' political activities and their relation to his artwork are difficult to appreciate. Some critics considered Beuys' political ideas as conservative or even reactionary. In the intellectual and political context after the war in Germany, it is rather obvious that Beuys tries to find a third way, leading out of the disaster of ideological dualities such as fascism versus communism. The innovative power of art was meant to find a new perspective beyond politically and intellectually proposed alternatives. Science and philosophy had been put to service by both regimes and art was thought to take over the moral and intellectual guidance lost in this process. The fact that both regimes had made modern art one of their major enemies left to art the duty to create new alternatives beyond traditional ideals and projects. A basic element of his program is the opposition against fixed or philosophical ideas, purporting dogmatic messages, or claiming a kind of intellectual leadership associated with manipulation, lying, and fraud given the experience of the war generation. Symbolic messages should avoid such deceptive strategies; they should instead be non-directive, bodily rooted, in continuity with natural signs and symbols. As a consequence, the new type of art had to deceive the expectation of the larger public socialized by the war regimes and still unable to free itself from the false securities implied by clear-cut programs and populist argumentation. In this sense, Beuys' art is a very natural outcome of post-war German progressive intellectualism.

Beuys shares the view of many poets and intellectuals that even language had been devaluated as a means of social communication by the totalitarian regimes. The late work of Ernst Cassirer, The Myth of the State (1946), describes how the official misuse of linguistic propaganda and the control of literature, science, and public utterances had corrupted the normality of language use such that, as an emigrant in the States, he had the impression that the German language used by the fascist regime had changed its basic function and, although phonetically similar, had lost its major signifying and communicative capacity. It thus became opaque to people like Cassirer who had left Germany in 1933. The writer (and insofar as the visual artist operates with linguistically transmitted concepts, also the painter and sculptor) had to change this basic semiotic medium underlying all other symbolic media in order to repair its malfunction, heal the symbolic diseases created by totalitarian regimes, the war and the crimes of deportation and mass executions during holocaust.

\section{Visual Artwork and Language}

With the emergence of abstract art (Duchamp 1911; Kandinsky 1913), reflective processes gained prominence in art, particularly in the artwork and writings of Paul Klee (1879-1940). Later gestures and movements/performances (possibly documented in film and video) came to the foreground; this is also characteristic for the work of Pollock after 1945 (cf. Wildgen 2010b). Complementary to the vanishing relevance of figurative art and the preponderance of reflective processes and a minimalist attitude (cf. Arte Povera; Art Informel; Minimal Art), this trend 
found many admirers and influenced active artists. As a general consequence, the conceptual background of art gained dominance over artistic (technical) performance. This line of development brought visual artwork into the neighborhood of linguistic thinking, because concepts and the underlying abstractions are typical linguistic achievements. Beuys said in an interview 1985:

My way was going through language, although this seems strange, it did not start from so called figural experiences. ${ }^{1}$

For Beuys, speaking corresponds to a kind of shaping of ideas and thus is akin to sculpture. Language as art is for Beuys primarily the play with language sounds and underlying concepts. Its primary goal is the creation of new social meaning. Rigid rules of syntax could be violated; the established items in a lexicon could be changed, filled with new meanings and functions. Art became, in this line of thought, a conceptual procedure (an operation with concrete forms, visual or spoken) and gave access to a non-visual space. The techniques of visual artwork focused on conceptual innovation were multiple:

- Graphical signs on surfaces.

- Diagrams (cf. next section).

- Sculptures (including interiors, installations).

- Actions with gestures, happenings with video documentation (accompanied by music).

Beuys' notion of language is nearer to its use in Dada poetry than in linguistics. The realm of different articulations is demonstrated in an 11 min presentation where Beuys repeats the words "Ja, $\mathrm{Ja}, \mathrm{Ja}, \mathrm{Ne}, \mathrm{Ne}, \mathrm{Ne}$ " (yes and no) in many tonal variants (cf. Beuys 1968). In his use of words and the associated concepts, he applies two techniques of innovation:

- Empty the meaning space either by reducing words to sounds (cf. Dada poetry) or by speaking to a dead animal (non audible to the public).

- "Play rock and roll" with words, throwing them around.

In one respect, Beuys sees language as a natural emanation of the human body; the human voice is a kind of artwork in itself (not dependent on the referential function it can have). In another respect, it is the manifestation of human thought and in this respect, it is instrumental, i.e. thought is the main feature; its expression through language is just a technique of enunciation (a channel of communication). Therefore the conventional architecture of language is rather a barrier, a filter that has to be overthrown, transgressed. The rigidness of the lexicon must be deconstructed in order to let new meanings emerge in context. ${ }^{2}$

\footnotetext{
1"Mein Weg ging durch die Sprache, so sonderbar es ist, er ging nicht von der sogenannten bildnerischen Erfahrung aus,” Beuys at the Munich ,Kammerspiele,“ 20th of November 1985; cited in: Blume and Nichols 2008, p. 64.

${ }^{2}$ This is rather common view in experimental poetry. Heidegger and (later in the same vein) Derrida have made a philosophical method out of this concept. Beuys is clearly related to experimental
} 


\section{Language as a Topic in His Visual Art}

Language is a major topic in Beuys' drawings and diagrams. Spoken language is like smoke from the chimney of a factory (Bodentafel II 1970, in Edinburgh, since 1984 in Schaffhausen, Hallen für neue Kunst). One could say it is the by-product of an industry of thinking, feeling, and other human bodily activities. Language is also a vocal gesture that we can observe either in lip-reading or in the X-ray film of a speaking person. At the Experimenta 3, in Frankfurt 1969, Beuys recited parts of the play Titus and Iphigenie, handled musical instruments and pointed at diagrams that described the movements of the human tongue that utters the word IPHIGENIE. Language is understood as a sound sculpture accompanied by gestures. In a drawing, Beuys associates diagrams of speech articulators with drinking from a jug; cf. Fig. 1.

The system of articulators is situated at a point of bifurcation in a more general dynamic field encompassing human will, human motion, and consciousness (“bewusstes Seelenleben”) (cf. Blume and Nichols 2008, p. 55). In a diagram, he describes his concept of language:

At the bottom, human volition ("Wille") is the source domain. At the level of the glottis (the bifurcation point in the diagram above), the unspecified stream of air is formed thanks to the elasticity of the cords and the plasticity of the vocal tract (above the diagram, Beuys mentions the different speech organs). It receives its specific content by the conscious soul and is finally converted into an utterance. The creativity of language may stand for artistic creativity in general or for the symbolic skills of man, which has an organic aspect related to the speech organs in the case

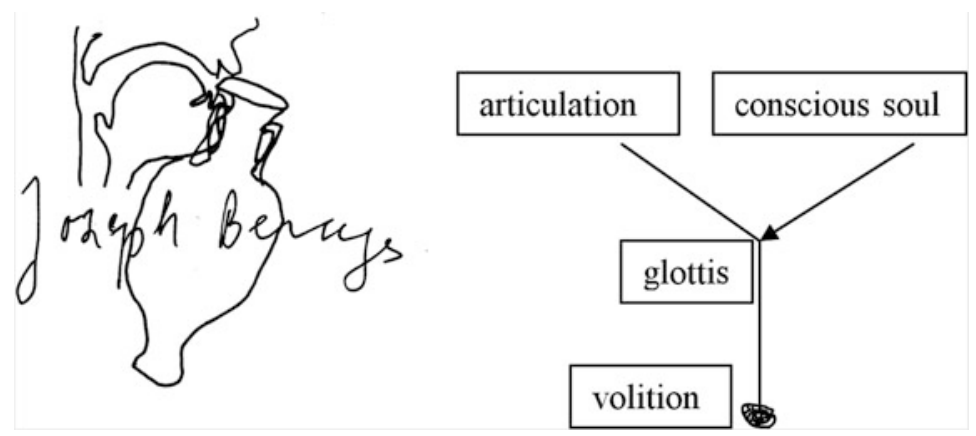

Fig. 1 Redrawn detail (W.W.) from Beuys' Iphigenie-Set, 1974, John Gibson Gallery, New York; cf. for a reproduction Blume and Nichols (2008, p. 55), and translation of the main concepts in a diagram (1960-1964, pencil on paper, DAS KAPITAL RAUM, 1970-1977, Hallen für Neue Kunst, Schaffhausen; cf. for a reproduction: Blume and Nichols [2008, p. 62])

poetry but no connection to Heidegger or Derrida can be established on the basis of his writings or talks (cf. Holzherr 2013). 
of language and to the hands of the sculptor in the case of the artist. The creation of forms is the expression of the force Beuys called "bewusstes Seelenleben."

After his dismissal from the academy in Düsseldorf (1969), written words on paper or blackboard accompanied by schemata and sketches became a major element in his actions on stage. I will comment some examples of his diagrammatic style in the next section.

\section{Diagrammatic Style in Beuys' Political Art}

Plain art objects, e.g. sculptures or paintings and even configurations of many objects as well as technical installations (cf. Beuys' honey pump) were not on a par with Beuys' pedagogical and political ambitions. To meet his own requirements, he began to devise utopian political programs, and organized international meetings. In his diagrams performed on blackboards or on the floor, he combined figurative drawings with graphical symbols (lines, circles, arrows) and written words. He relates this style to Leonardo's codices (cf.: Blume and Nichols 2008, p. 230); a corresponding drawing was shown by Beuys in 1975: Hearing, Seeing, Feeling (cf. ibid., p. 231).

In Beuys' drawing from 1975, diagrammatic elements point to processes like: listening, seeing (e.g. the "channels" leading to the eyes and to the right ear) and feeling (e.g. the arrows from the waist to the head). In this example, the pictorial aspects still dominate the diagrammatic ones. In another artwork, Beuys returns to the technical use of diagrams: here, the chart paper for medical measurements or, as the title indicates, for the measurement of earthquakes. In these cases, diagrams function without further pictorial or linguistic specifications (Diagramma Terramoto, pencil on a cardiographic millimetre paper, shown by Ackermann and Malz [2010, p. 274] and, in several instances, on the net: http://www.exibart.com/ foto/55724.jpg).

The main class of diagrams produced by Beuys combined pictorial and linguistic features and comes near to typical black board structures produced in the classroom and with a pedagogical aim. In a diagram from the same period (1972), he used logical oppositions written on paper or on a blackboard and combined with arrows, lines, and simple pictures. We find specific scales of concepts:

- Chaos - order; birth - death; cold - warmth; volition - feeling - thinking (Chaos - Ordnung; Geburt - Tod; Wärme - Kälte; Willen - Gefühl - Denken). In these scales with two or three values, one could be tempted to recognize the "semiotic square" introduced in Greimas (1970); but Beuys refers only to the classical Aristotelian technique of contraries.

- Order and form are depicted by crystals (regular solids). This is a classical topic since Plato's dialogue “Timaeus." Leonardo, Dürer, Kepler, Goethe, and many others in the Platonic tradition referred to regular solids and crystals to explain regularity in nature. The opposite - chaos, turbulence - is represented 


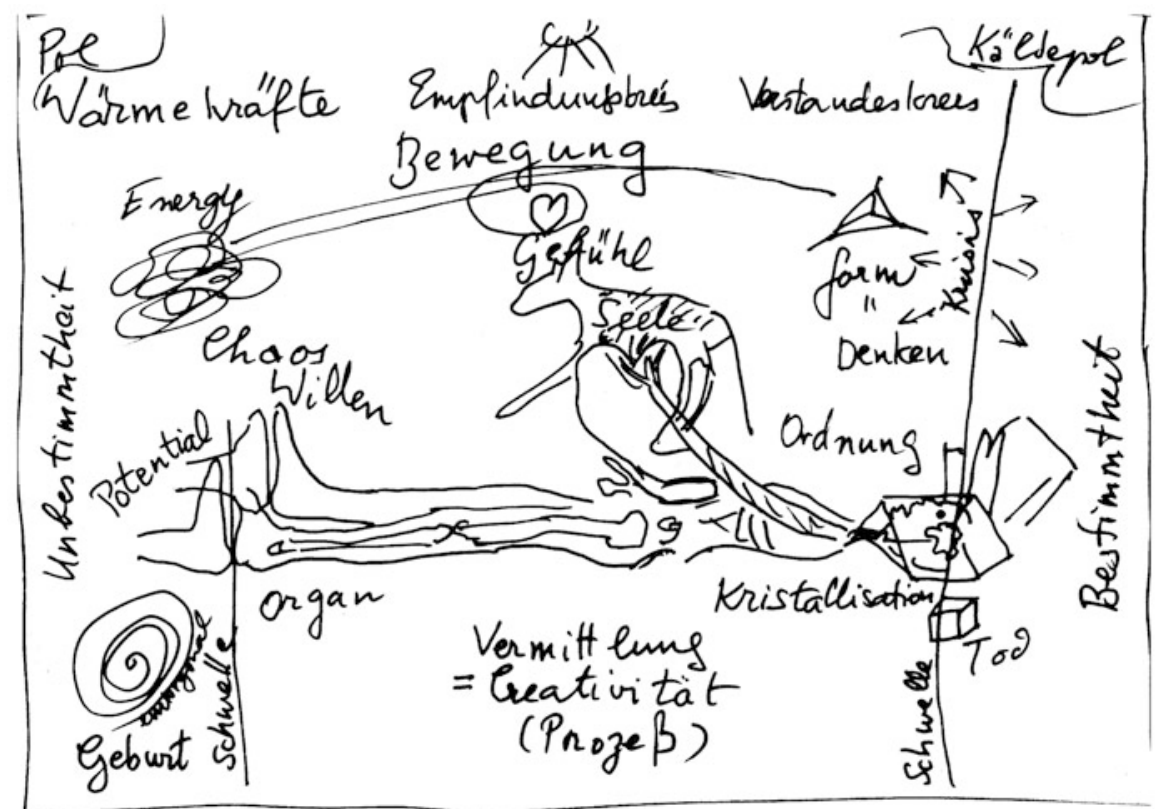

Fig. 2 Selectively redrawn diagram (W.W.), Beuys, Untitled, 1972, Sammlung Klüser, München (cf. for a reproduction of the original: Ackermann and Malz [2010, p. 261])

by spirals and quasi-chaos attractors. In Fig. 2, we recognize a human body lying on the floor. At its basis, the level of the feet, we see a cloud of ellipses (with the associated concepts [in German]: Energie; Chaos) and a spiral (with the associated concept: Embryonen) and under the body a scale: birth (Geburt) to death (Tod). The body has in place of the head a crystal (Kristall) accompanied by a cube (below) and a pyramid (above). The area between is one of mediation (Vermittlung) and is called the area of creativity (Kreativität). In a broadcasted discussion (Club2 1983; cf. internet sources) with György Ligeti and others, Beuys insisted that the totality of human capacities, i.e. intuition, imagination and logical thinking must be involved in art and he does not accept the reduction of art to simply imagination and intuition (which would exclude logical and scientific thinking).

Different drawings/diagrams allude to mathematical forms in nature and art and to concepts in the natural sciences:

- Regular solids (in the vein of Leonardo da Vinci and Dürer).

- Crystallization as an inorganic process (which produces regular shapes).

- Embryology (cf. René Thom's morphogenetic models; cf. Thom [1972]),

- Energy flow (warmth) and thermodynamics (cf. Prigogine's "non-equilibrium processes and dissipative structures," e.g. in Prigogine [1980, ch. V-VI]). 


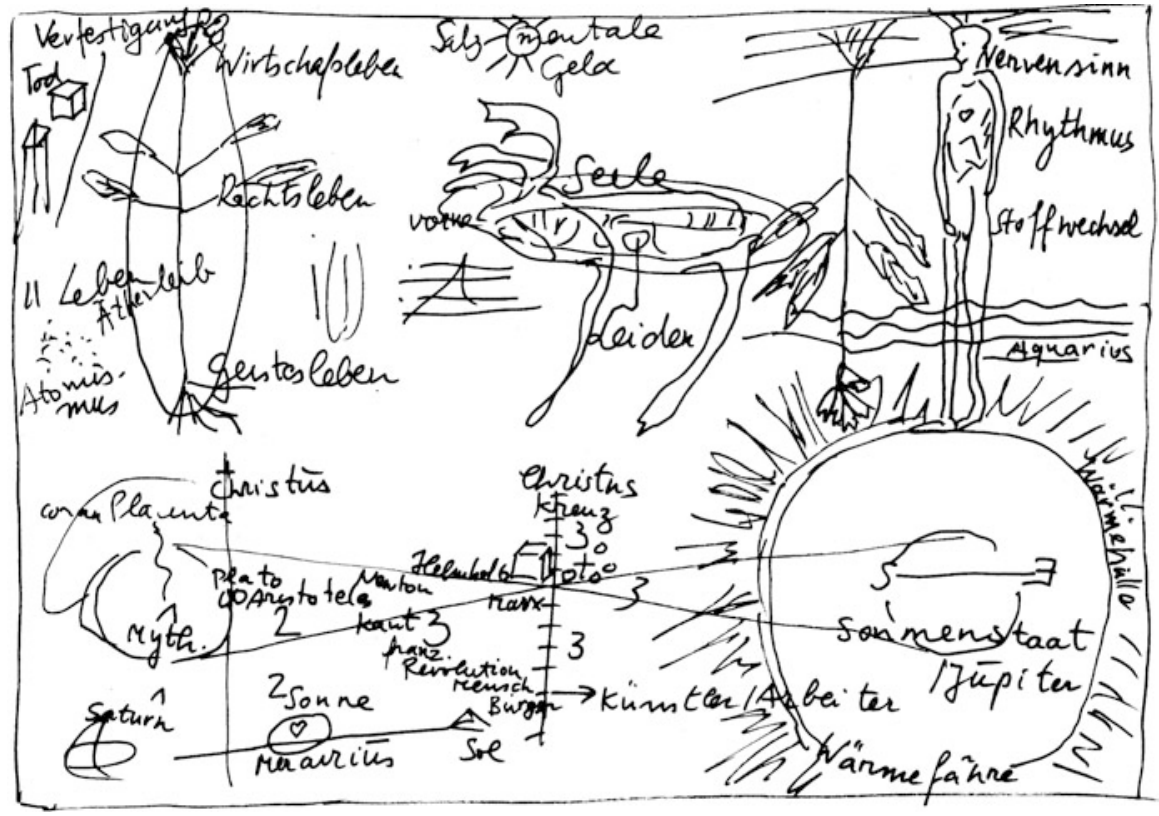

Fig. 3 Selectively redrawn diagram (W.W.), Beuys, Untitled (Evolution), 1974 (private collection; cf. for a reproduction Blume and Nichols [2008, p. 313])

In fact, most diagrams are rather an accumulation of many diagrams with similar topics in one drawing or complex schema. Figure 3 is an example of such a complex arrangement, which combines drawings, diagrams and words.

The diagram named "Evolution" combines very different categories:

- A human body, a deer, plants, crystals, water, the sun.

- Social entities and phenomena: citizen - artist - worker; intellectual life juridical life - economic life (Bürger - Künstler - Arbeiter; Geistesleben Rechtsleben - Wirtschaftsleben).

- Names of philosophers on a historical scale: Plato/Aristotle, Newton/Kant/Helmholtz, Marx. At the extremes of the horizontal time scale stands Christ.

- The dominating drawing at the right is based on the sun and its rays (warmth) and supports pictures of the human body, the structure of a plant (cf. Goethe) and the deer (symbol of the light, the sun and the soul). Beuys had his own theory of (social) warmth, which may be associated with Peirce's agapism (end of the nineteenth century) and social theories opposed to social Darwinism, which dominated many economic and political ideologies at the beginning of the twentieth century. 


\section{Beuys' Diagrams and Peirce's Theory of Diagrams}

Beuys refers several times to Leonardo da Vinci and Dürer in his work; both stand for the integration of contemporary science (and philosophy) in art (cf. Wildgen 2004, 2010a). In relation to modern art, Beuys' diagrammatic art points back to the Bauhaus tradition (and similar European traditions), more specifically to Paul Klee (1879-1940), who used diagrams in his teaching at the Bauhaus after 1920 (cf. Klee 1925). As the Bauhaus tradition stands for the integration of technical art (architecture), design, and visual art, it continues the Renaissance tradition initiated by Leonardo da Vinci and Dürer. In a philosophical perspective, one can even compare Beuys' diagrammatic style with the use of diagrams and visualization in the computerized world of contemporary natural sciences. I shall only give some hints, which can be discussed more thoroughly in the context of the semiotics of diagrams (cf. Stjernfelt 2007). The starting line is Charles Sanders Peirce's diagrammatic logic.

Peirce's diagrammatic logic and Beuys' diagrams only share the appeal to vision and visual cognition. The deductive power of Peirce's diagrammatic logic has no parallel in Beuys' diagrams; they are mainly suggestive or metaphorical devices. In an article on Kepler, Peirce distinguishes Kepler's imagination, which enables "a mental diagram of a complicated state of facts," from a poet's imagination, which "riots in ornaments and accessories" (Peirce 1958, p. 255). Kepler looks at the world "with an eye of sadness, without tears, yet without illusion." Beuys' diagrams correspond to a poet's imagination; they are optimistic and represent the result of a consideration of many relevant forces. The transition from one diagrammatic project to the other could be smooth, but the characters of the agents are different. Beuys is rather a utopian optimist; Peirce prefers the cool vision of Kepler and other naturalists.

It is evident that Beuys is not a scientist and that his conceptualizations are not a pathway towards a scientific model in the strict sense (they may be the sketch of a theory in the humanities, however). On the other hand, innovative science has to start from theoretical intuitions which can be sketched diagrammatically and later lead to exact theories if a proper mathematical formulation is found and if the predictions of such a model are checked in experiments or evaluated in relation to given observations (in qualitative models).

In his dictum "Kapital = erweiterter Kunstbegriff" (Capital = enlarged notion of art), Beuys refers first to the human creative (artistic) capacity, which is a capital for humanity. Next (in relation to Marx), he says that the products themselves, if exchanged for money, may become a kind of generalized goods of exchange; the artists in a society are then "means of production," a "Capital," which is owned only by the artists themselves. If the (industrial) products become more or less media of identity and social communication and are embedded in a circulation and flow of money, they function like artwork. They become a means of communication and are embedded in the economic flow of money, here conceived as the overarching level of economic reality. 
As a corollary, Beuys may argue that the inability of scientific theories of the market (and the economic engineering applying these theories) to bring about a global change and to avoid imminent catastrophes leaves the artist with the duty to shape the future society (as a social sculpture). Art becomes a kind of political planning and experimental economy. This was certainly a utopia in the seventies and eighties, but only future will show if art can at least partially fulfill such a political and economic task.

Beuys became one the best paid artists in the world at the end of his life. His art and that of other successful artists in our time (behind whom stand an army of artists without any access to economic values) are used on a par with actions, gold, real estate and other assets.

\section{The Aesthetic "Value" of Beuys' Art}

My answer to the question of evaluation of art and specifically the art of Beuys can only be a preliminary one because the process of evaluation and re-evaluation is still going on three decades after his death. The concepts of art evaluation have been explicitly discussed by Ingarden (1969, papers VI-XI) who tries to propose a lexicon of evaluative adjectives ordered on different scales (material moments, formal moments, variations of specific qualities, etc.). I shall just propose some aspects relative to which Beuys' art may be evaluated:

1. As in other pieces of modern art, the material value is often low (simple, cheap materials are used). The value of the materials cannot stand for the value of art (in the same sense the value of paper used for a $50 \$$ bill cannot stand for the exchange value of the bank bill).

2. The temporal scope of the artwork is rather limited, i.e. the evaluation concerns an artwork in its execution, in a specific situation, or in a restricted period of its existence (e.g. the 2 months of the Biennale in Venice for Beuys' "tramway station"). The resulting pieces stocked in a museum or sold as multiples in art auctions cannot be the primary object of aesthetic evaluation although they define the economic value (the price) of the artwork.

3. Many of his artworks have biographical memory values. The question is then: do these biographical memory values (concerning situations in Beuys' life) have an aesthetic value for the larger public, which does not share these memories?

4. Beuys' art typically reflects a "Zeitgeist," i.e. it has a value for some community (e.g., Germany or Europe) in a specific period (e.g., the sixties and seventies) insofar as it captures this "Zeitgeist." How does this value evolve over time? Is it likely to fade away? This is also a criterion for the evaluation of his artwork as "social sculpture." Did the "sculpture" influence political reality? Was it understood by the political rulers or by the population? Did it change the votes or the architecture of political parties or at least the intellectual atmosphere in political discourse? 
5. Finally, the investment of personal life in the artwork is a criterion. The value of Beuys' installations and performances depended essentially on his bodily presence (including the hat he was permanently wearing in public). How did this value change after his death?

The criteria are certainly important for the evaluation of Beuys' artwork. The important questions are: How can they be computed to an overall judgment? Is such integration possible (in light of the heterogeneity of the criteria involved) and, if so, is the product stable over time (and in the population of collectors, art critiques, and the community interested in art)? Strangely enough, it seems that the value of artworks is very stable, although many political revolutions have shown sudden breakdowns or the destruction of artworks for religious reasons.

\section{Conclusion}

In this case study centered in the artwork of Joseph Beuys, it became clear that the ontological (substantial, material) nature of artwork was reduced or radically changed from stable, expensive and technically difficult materials and techniques of production to simple, almost worthless materials and to performances only existing for a short period of time and in restricted contexts (cf. Beuys explaining his drawings to a dead hare in a room without a public apart from the photographer and a television crew). What is left from the phenomenology of classical art experience? Are there specific "brain states or neural dynamics that correspond to that phenomenology" (cf. the statement in the introduction to this book)?

The traditional art recipient or the visitor in art museums may conclude that this is not art (as did the American president in 1913 in New York viewing modern European art and as did Hitler when he decided to destroy modern artworks after 1938). One century after the Armory show in New York that scandalized Roosevelt, we know that modern art took the path of innovation and avant-garde and continued it until today, and that a steadily increasing public has been able to follow this path. This means that the human brain is able to adapt to changing modes in art and that avant-garde artists are able to impose their experimental innovations on a larger public. This is the first observation we can make after a century of scandals caused by modern art. If we look closer, we may see that, beyond a few trends which have been accepted, a myriad of artistic experiments were made which had no impact on the public and that those which were successful needed assistance from other forces: either organized groups, the media, or the economical and political influence of sponsors, collectors, and art experts. Some, like Picasso, Dali, and, to a lesser extent, Beuys, were also very successful by themselves in gaining public attention and imposing their style on the market and among art experts. They intuitively or rationally used modern means of propaganda: Picasso and his women portrayed in many pieces of art; Dali and his eccentric behavior in public, Beuys in his special dress with his hat on. 
On a more general level, the lesson taught by modern art says that human experience of art is, on one side, very open and can be adapted to new experiences. On the other side, it is guided by social processes, be they local such as groups or centers of art (cf. the role of art communities in Paris or in New York) or global such as the cultural changes after the wars (1919 and 1946). In the work of Beuys, the dimension of reflective processes, art theories, and art politics (even of a utopia where artists shape society or humanity) became a prominent factor. Meanwhile, this trend may have lost its fascination but it can be expected that it will show up again under specific conditions. Permanent change seems to be the distinctive mark of art in the modern world.

Open Access This chapter is distributed under the terms of the Creative Commons Attribution Noncommercial License, which permits any noncommercial use, distribution, and reproduction in any medium, provided the original author(s) and source are credited.

\section{References}

Ackermann, Marion and Isabelle Malz. 2010. Joseph Beuys. München: Parallelprozesse, Schirmer/Mosel.

Beyaert-Geslin, Anne. 2012. Sémiotique du design. Paris: Presses universitaires de France.

Blume, Eugen, and Catherine Nichols (eds.). 2008. Beuys: Die Revolution sind wir. Göttingen: Steidl.

Cassirer, Ernst. 1946/1974. The myth of the state. Yale: Yale University Press.

Greimas, Algirdas Julien. 1970. Du sens: Essais sémiotiques. Paris: Seuil.

Ingarden, Roman. 1969. Erlebnis, Kunstwerk und Welt. Vorträge zur Ästhetik 1937-1967. Darmstadt: Wissenschaftliche Buchgesellschaft.

Klee, Paul. 1925. Pädagogisches Skizzenbuch. München: Langen.

Peirce, Charles Sanders. 1958. Selected writings (Values in a universe of chance), ed. Philip P. Wiener. New York: Dover Publications.

Prigogine, Ilya. 1980. From being to becoming: Time and complexity in physical sciences. New York: Freeman.

Stachelhaus, Heiner. 1987/1991. Joseph Beuys, 3rd ed. Düsseldorf: Econ.

Stjernfelt, Frederik. 2007. Diagrammatology: An investigation on the borderlines of phenomenology, ontology, and semiotics. Berlin/Dordrecht: Springer.

Thom, René. 1972/1975. Stabilité structurelle et morphogenèse. Paris: Interéditions.

Wildgen, Wolfgang. 2004. Conceptual innovation in art. Three case studies on Leonardo da Vinci, William Turner, and Henry Moore. In Seduction, community, and speech: A Festschrift for Herman Parret, ed. Frank Brisard, Michael Meeuwis, and Bart Vandenabeele, 183-196. Amsterdam: Benjamins.

Wildgen, Wolfgang. 2010a. Geometry and dynamics in the art of Leonardo da Vinci. Cognitive Semiotics 5: 1-30.

Wildgen, Wolfgang. 2010b. Chaos und Ordnung in der abstrakten Kunst der Moderne. Kodikas/Code 33(1-2): 101-121.

Wildgen, Wolfgang. 2013. Visuelle Semiotik. Die Entfaltung des Sichtbaren. Vom Höhlenbild bis zur modernen Stadt. Bielefeld: Transcript. 


\section{Internet Sources with Actions and Discussions}

Beuys, Joseph. 1968. Ja Ja Ja Ne Ne Ne excerpt. http://www.youtube.com/watch?v=PFGf_ y4JyOA.

Beuys in Club 2. 1983. http://www.youtube.com/watch?v=J6pS7H_24CE.

Holzherr, Martin. 2013. Beuys und das Raunen. In Spektrum der Wissenschaft, Scilogs, 15.05.2013; cf. http://www.scilogs.de/chrono/blog/denkmale/allgemein/2013-05-15/neue-beuys-biografie. 